\section{IAC Nuance and IAC Tigre: common bean cultivars for special markets}

\author{
Sérgio Augusto Morais Carbonell ${ }^{1}$, Alisson Fernando Chiorato ${ }^{1}$, \\ Luiza Maria Capanema Bezerra ${ }^{1}$, João Guilherme Ribeiro \\ Gonçalves ${ }^{1}$, Daiana Alves da Silva ${ }^{1 *}$, José Antônio de Fátima \\ Esteves ${ }^{1}$, Luciana Lasry Benchimol Reis ${ }^{2}$, Cássia Regina Limonta \\ Carvalho², Vera Lúcia Nishijima Paes de Barros ${ }^{3}$, Rogério Soares \\ de Freitas ${ }^{4}$, Marcelo Ticelli ${ }^{5}$ and Paulo Boller Gallo ${ }^{6}$
}

\begin{abstract}
IAC Nuance and IAC Tigre are special common bean cultivars for consumption in Brazil and for international markets. IAC Nuance has a 75-day cycle, with cranberry type rajado (streaked/dappled) bean seeds. IAC Tigre has 85-day cycle, a cream-colored seed coat with brown specks (pinto bean type). These cultivars are moderately resistant to anthracnose, angular leaf spot, fusarium wilt, common bacterial blight, and bacterial wilt.
\end{abstract}

Keywords: Phaseolus vulgaris L., plant breeding, cranberry beans, pinto beans.

\section{INTRODUCTION}

In Brazil, growing common bean (dry edible bean) in production systems directed to commercialization has presented different demands than the traditional (Chiorato et al. 2018). Thus, the bean breeding programs, traditionally directed to developing carioca or black bean groups, have sought to develop new "special bean grains" cultivars to respond to new consumer. These special grains include those with white, red, cream-colored, and yellow seed coats, with and without stripes, and of varied sizes.

According to Ribeiro et al. (2014), the production of special bean grains in Brazil is only in the beginning stage due to the lack of adapted cultivars with high yield. Within this context, public research organizations have offered new cultivars of the rajado commercial group, which include cranberry and pinto type beans, to Brazilian producers, aiming to diversify production and obtain access to the export market (APTA 2018).

It is important to highlight that these demands are of a specified nature that vary according to consumer markets characterized by locally and regionally differentiated tastes and preferences. Whereas the Brazilian consumer market has a preference for carioca and black bean groups, in the world consumer market there is predominance of beans with diverse characteristics, such as Andean (cranberry, alúbia, jalo, DRK) and Mesoamerican (black, navy, and pinto) bean grains.

Due to concentration of production in carioca common bean, Brazilian farmers have had to bear price declines in periods in which product stocks increase and
Crop Breeding and Applied Biotechnology 20(3): e26732035, 2020 Brazilian Society of Plant Breeding. Printed in Brazil http://dx.doi.org/10.1590/198470332020v20n3c39

\author{
*Corresponding author: \\ E-mail: daiagrouel2002@hotmail.com \\ (i) ORCID: 0000-0002-4211-3308 \\ Received: 16 April 2019 \\ Accepted: 21 October 2019 \\ Published: 20 July 2020
}

${ }^{1}$ Instituto Agronômico de Campinas, Centro de Análises e Pesquisa Tecnológica do Agronegócio dos Grãos e Fibras, 13.020-902,

Campinas, SP, Brazil

${ }^{2}$ Instituto Agronômico de Campinas, Centro de Pesquisa e Desenvolvimento de Recursos Genéticos Vegetais, 13.020-902, Campinas, SP, Brazil

${ }^{3}$ Agência Paulista de Tecnologia dos Negócios, Pólo Regional de Desenvolvimento Tecnológico do Agronegócio, 18.300-970, Capão Bonito, SP, Brazil

${ }^{4}$ Instituto Agronômico - IAC, Centro APTA de Seringueira e Sistemas Agroflorestais, 15.500000 , Votuporanga, SP, Brazil

${ }^{5}$ Agência Paulista de Tecnologia dos Negócios Sudoeste Paulista, Pólo Regional de Desenvolvimento Tecnológico do Agronegócio, 18.300-970, Tatuí, SP, Brazil

${ }^{6}$ Agência Paulista de Tecnologia dos Negócios Nordeste Paulista, Pólo Regional de Desenvolvimento Tecnológico do Agronegócio, 13.730-980, Mococa, SP, Brazil 
supply is excessive. For carioca bean production, sale of excess stocks on the international market is not an alternative, because there is low demand for this type. These special bean grains have not yet won widespread acceptance from the Brazilian consumer, probably due to their reduced supply and higher price (Chiorato et al. 2008, Melo et al. 2014).

Thus, breeding programs have sought to develop new cultivars that promote variability of common bean types for consumption in Brazil, adding value and allowing the opening of new international markets. The Common Bean Breeding Program of the Instituto Agronômico (PMGF-IAC) invested resources in 2001 to create a new line of research directed to bean grains other than carioca and black, registering six cultivars with special bean grains beginning in 2007.

With the aim of releasing new technological products in the common bean production chain in Brazil, the PMGFIAC registered the special bean grain cultivars IAC Nuance and IAC Tigre in the Registro Nacional de Cultivares (National Cultivar Registry) of the Ministério da Agricultura, Pecuária e Abastecimento (Brazilian Ministry of Agriculture) - MAPA/ RNC in 2016.

\section{GENETIC ORIGIN AND DEVELOPMENT}

The cultivars IAC Nuance and IAC Tigre were developed in 2006 from crosses between the cultivar Hooter $x$ line Gen 99TG8-83 and the cultivars North Dakota x IAPAR 31, respectively. The Hooter cultivar is of U.S. origin and has cranberry seed coat. The Gen 99TG8-83 line was developed by the PMGF-IAC and was derived from the cross between the cultivars IAC Carioca Aruã $\times$ Pompador. The cultivar North Dakota, with a white seed coat and resistance to common bacterial blight, was crossed with IAPAR 31, with a pinto bean seed coat, high yield, and anthracnose resistance.

The $F_{2}$ plants of the cross between Hooter $\times$ Gen 99TG8-83 and North Dakota $\times$ IAPAR 31 were inoculated in the laboratory with a mixture of races 31,65 , and 89 of the anthracnose (Colletotrichum lindemunthianum) pathogen. After selection of plants resistant to anthracnose, the generations began to be advanced and evaluations were made of agronomic traits of interest to the PMGF IAC.

In the cross Hooter $\times$ Gen99TG8-83, 40 plants resistant to anthracnose were selected, among them the plant Gen OTG07 with cranberry seed coat, and in the cross North Dakota $\times$ IAPAR 31, the progeny Gen OTG07-10 was selected, characterized by upright plant architecture and pinto bean seed coat.

After advancing the generations by self-pollination and observation of the characteristics of agronomic interest, the progenies Gen OTG07-4 (IAC Nuance) and GenOTG07-10 (IAC Tigre) were selected in 2007, and in 2010 the Valor de Cultivo e Uso - VCU (Value for Cultivation and Use) trials began for these special bean lines.

The VCU experiments for the Gen OTG07-4 and Gen OTG07-10 lines were conducted in randomized blocks with 3 replications, using the cultivars IAC Boreal and IAC Harmonia as controls, in the main production regions of the state of São Paulo for the three crop seasons (rainy, dry, and winter). The abbreviation Gen OTG was attributed to the line to highlight Genetics (Gen) and Other Types of (Bean) Grain (OTG), for the purpose of differentiating it from the group for classification of carioca and black seed coat genotypes.

\section{YIELD CAPACITY}

The VCU experiments were conducted in 18 environments for three crop seasons from 2010 to 2011. The experiments were set up in the municipalities according to the crop season: 2010/rainy (Mococa, Capão Bonito, and Tatui), 2010/dry (Tatui, Avaré, and Capão Bonito), 2010/winter (Votuporanga, Ribeirão Preto, and Colina), 2011/rainy (Mococa, Avaré, and Tatui), 2011/dry (Tatui, Avaré, and Capão Bonito), and 2011/winter (Votuporanga, Ribeirão Preto, and Colina). It is important to note that the cultivars IAC Nuance and IAC Tigre were developed at that time (from 2010 to 2011), but were kept until the right time for the market to launch, as at that time the consumption of special grains was not well established.

The results of combined analysis of the 18 VCU experiments (Table 1) show that the lines Gen OTG07-4 (IAC Nuance) and Gen OTG07-10 (IAC Tigre) were superior in absolute values to the mean of the controls IAC Boreal and IAC Harmonia $\left(1984.25 \mathrm{~kg} \mathrm{ha}^{-1}\right)$, with mean yields of $2158 \mathrm{~kg} \mathrm{ha}^{-1}$ and $2311 \mathrm{~kg} \mathrm{ha}^{-1}$, respectively. When compared by the Dunnett means test at $5 \%$ probability, the values were not significant. In these experiments by crop season, the lines Gen OTG07-4 (IAC Nuance) and Gen OTG07-10 (IAC Tigre) were also superior in absolute values compared to the mean of the controls. 
Table 1. Bean grain yield $\left(\mathrm{kg} \mathrm{ha}^{-1}\right)$ in VCU experiments conducted in 18 environments of the state of São Paulo in three crop seasons in the $2010 / 2011$ biennial period

\begin{tabular}{|c|c|c|c|c|}
\hline \multirow{2}{*}{$\begin{array}{l}\text { Common } \\
\text { Bean Cultivar }\end{array}$} & \multicolumn{3}{|c|}{ Crop season } & \multirow{2}{*}{$\begin{array}{c}\text { Mean } \\
2010 / 2011 \\
\left(\mathrm{~kg} \mathrm{ha}^{-1}\right)\end{array}$} \\
\hline & $\begin{array}{c}\text { Rainy } \\
\text { (6 environments) }\end{array}$ & $\begin{array}{c}\text { Dry } \\
\text { (6 environments) }\end{array}$ & $\begin{array}{c}\text { Winter } \\
\text { (6 environments) }\end{array}$ & \\
\hline IAC Nuance & 2026 & 2479 & 1967 & 2158 \\
\hline IAC Tigre & 2006 & 2657 & 2268 & 2311 \\
\hline IAC Boreal & 1601 & 2252 & 1815 & 1889 \\
\hline Mean of controls $\left(\mathrm{kg} \mathrm{ha}^{-1}\right)$ & 1723 & 2364 & 1865 & 1984 \\
\hline CV (\%) & 16.34 & 13.14 & 13.42 & 14.49 \\
\hline $\operatorname{MDS}\left(\mathrm{kg} \mathrm{ha}^{-1}\right)^{*}$ & 673 & 510 & 566 & 342 \\
\hline
\end{tabular}

* Means test performed by the Dunnett method at $5 \%$ probability using the cultivars IAC Harmonia and IAC Boreal as standard controls.

\section{OTHER CHARACTERISTICS}

IAC Nuance is a cultivar with semi-upright plant architecture and Type I determinate growth habit. It has a 1000 seed weight of approximately 510 grams. Its mean cycle is 75 days from emergence to physiological maturity in accordance with environmental growing conditions, considered an early cycle cultivar. The cultivar IAC Nuance has a cranberry type streaked/dappled bean grain with predominant cream-color and reddish stripes.

IAC Tigre has semi-upright plant architecture and a Type II indeterminate growth habit. Its mean cycle from emergence to physiological maturity is 85 days. It has a 1000 seed weight of 350 grams and a cream-colored seed coat with light brown specks across the entire surface (pinto bean).

Under natural growing conditions, the cultivars IAC Nuance and IAC Tigre are moderately resistant to anthracnose (Colletotrichum lindemuthianum), angular leaf spot (Phaeoisariopsis griseola), Fusarium wilt (Fusarium oxysporum), common bacterial blight (Xanthomonas axonopodis pv. phaseoli), and bacterial wilt (Curtobacterium flaccumfaciens pv. flaccumfaciens).

As shown in Table 2, no significant difference was observed between the cultivars IAC Nuance and IAC Tigre in relation to the controls for mean cooking time (minutes) and crude protein content (\%). In combined analysis and also according to crop season, IAC Nuance and IAC Tigre have values for cooking time and protein content similar to the controls. For the four cultivars studied, variation in mean cooking time was only $1 \mathrm{~min} 40 \mathrm{sec}$ and for protein content percentage, it was $0.5 \%$.

\section{TECHNICAL RECOMMENDATIONS AND SEED PRODUCTION}

The cultivars IAC Nuance and IAC Tigre are recommended for cultivation in the rainy, dry, and winter crop seasons in the state of São Paulo and may also be recommended for the rainy and dry crop seasons in the states of Paraná, Santa Catarina, Rio Grande do Sul, and Mato Grosso do Sul. IAC Nuance was registered in MAPA/RNC in 2016 under number 36017, and IAC Tigre under number 36014.

Table 2. Technological and nutritional quality: mean values of cooking time by the Mattson cooker and percentage of protein in common bean seeds cultivated in 18 environments in the state of São Paulo in the 2010/2011 biennial period

\begin{tabular}{lcccccccc}
\hline \multirow{2}{*}{$\begin{array}{l}\text { Crop } \\
\text { season }\end{array}$} & \multicolumn{2}{c}{ IAC Nuance } & \multicolumn{2}{c}{ IAC Tigre } & \multicolumn{2}{c}{ IAC Boreal } & \multicolumn{2}{c}{ IAC Harmonia } \\
\cline { 2 - 8 } & $\begin{array}{c}\text { Cooking time } \\
(\mathrm{min})\end{array}$ & $\begin{array}{c}\text { Protein } \\
\text { content }(\%)\end{array}$ & $\begin{array}{c}\text { Cooking time } \\
(\mathrm{min})\end{array}$ & $\begin{array}{c}\text { Protein } \\
\text { content }(\%)\end{array}$ & $\begin{array}{c}\text { Cooking time } \\
(\mathrm{min})\end{array}$ & $\begin{array}{c}\text { Protein } \\
\text { content }(\%)\end{array}$ & $\begin{array}{c}\text { Cooking time } \\
(\mathrm{min})\end{array}$ & $\begin{array}{c}\text { Protein } \\
\text { content (\%) }\end{array}$ \\
\hline Rainy & 32.76 & 19.5 & 29.9 & 20.5 & 32.85 & 20.5 & 32.2 & 20 \\
Dry & 34.84 & 21 & 31.78 & 20 & 34.2 & 21 & 33.28 & 19.5 \\
Winter & 33.37 & 21 & 32.25 & 21 & 36.35 & 20.5 & 33.84 & 20.5 \\
\hline Mean & 33.66 & 20.50 & 31.31 & 20.50 & 34.47 & 20.67 & 33.11 \\
\hline
\end{tabular}


A between-row spacing of $50 \mathrm{~cm}$ and 10 final (emerged) plants per linear meter are recommended for both cultivars, resulting in 200.000 plants per hectare. Seeds are available at the Seed Production Center of the Instituto Agronômico - IAC.

\section{REFERENCES}

APTA - Agência Paulista de Tecnologia dos Agronegócios (2018) IAC Nuance conquista o mercado antes mesmo de completar um ano de lançamento. Série publicações APTA, Campinas, 104p.

Chiorato AF, Carbonell SAM, Ito MF, Benchiomol LL, Colombo CA, Perina EF, Ito MA, Junior ER, Freitas RS and Pereira CVN (2008) IAC-Boreal and IAC-Harmonia: common bean cultivars with striped grains. Crop Breeding and Applied Biotechnology 8: 170-173.

Chiorato AF, Reis LLB, Capanema LM and Carbonell SAM (2018) Global vision on common bean breeding cultivars. In Rocio Campos-Vega (Org.) Phaseolus vulgaris: cultivars, production and uses. $1^{\text {st }}$ edn, Nova
Science Publishers, New York, p. 1-41.

Melo LC, Abreu AFB, Ramalho MAP, Carneiro JES, Paula Júnior TJ, Peloso MJ, Pereira HS, Faria LC, Pereira Filho IA, Moreira JAA, Martins M, Vieira RF, Martins FAD, Coelho MAO, Costa JGC, Wendland A, Santos JB, Dias JLC, Carneiro PCS, Giúdice MPD and Faria JC (2014) BRSMG Realce: Common bean cultivar with striped grains for the state of Minas Gerais. Crop Breeding and Applied Biotechnology 14: 61-64.

Ribeiro ND, Rodrigues JA, Prigol M, Nogueira CW, Storck L and Gruhn EM (2014) Evaluation of special grains bean lines for grain yield, cooking time and mineral concentrations. Crop Breeding and Applied Biotechnology 14: 15-22. 